\title{
Pedagogical Mechanisms of the System of Preparation of Future Teachers for Higher Educational Institutions for Social and Pedagogical Activity
}

\author{
Mamatkhanova Nargiza Tokhirovna \\ $\mathrm{PhD}$ researcher, Namangan State University
}

\begin{abstract}
The article provides ideas for improving the pedagogical mechanisms of preparation of future teachers of higher education institutions for socio-pedagogical activities, the work of teachers and members of the scientific community. Also, the management of the higher education system in accordance with the needs of the students of the period is an integral part of socio-pedagogical management in society. It was noted that in order to create certain conditions for students, it is necessary to constantly develop the activities of the educational institution. It is noted that the state of education in the near future is planned on a scientific basis, and the professional training of future teachers is associated with the problem of preparation for socio-pedagogical activities.

The peculiarities of the management of educational activities in the process of continuing education, including higher education, is a comprehensive vision of the work of the educational institution and its organization at the level of modern requirements. It plays an important role in improving the efficiency and effectiveness of the internal management system of the educational institution, directly in the organization of educational work of students on the basis of new requirements. Its purpose is to organize educational work for professionals - future teachers in accordance with the requirements of the developing period of civil society. The requirements of the social society to higher education include advanced pedagogical practices, based on modern pedagogical technologies, enrichment and improvement in effective ways to develop sociopedagogical activities in students.

It was noted that in the context of modernization of education, the requirements for the content of higher education, the development of training of future teachers for socio-pedagogical activities have increased. The analysis of the development of the supply of textbooks for students of pedagogy and psychology of higher education institutions to increase their interest in knowledge related to the preparation for socio-pedagogical activities, while knowing the problems of science in the classroom.
\end{abstract}

Key words: education, pedagogue-psychologist, student, socio-pedagogical activity, training.

\section{INTRODUCTION}

It should be noted that higher education institutions are an important educational link in the development of spirituality of young people and the preparation of future teachers for sociopedagogical activities. At the present time, it is important to connect young people with the life and 
goals of the transforming global societies, to help young people find their place in society. The need to integrate the education system with the political, economic, socio-pedagogical and spiritual changes of society is becoming a task. As Sh.M.Mirzyoev noted, "We consider it our primary task to improve the activities of all links of the education system on the basis of modern requirements" (Mirziyoyev Sh.M. 2017).

The process of deep integration of students into modern times in higher education is an event that is inextricably linked with the preparation for socio-pedagogical activities. In educating young people, preparing them for socio-pedagogical activities in today's world of radical social change, this issue can not be considered fully studied. Accordingly, it is important to study the issues of pedagogical mechanisms for preparing future teachers of higher education institutions for socio-pedagogical activities.

At the same time, students of higher education in the field of pedagogy and psychology fully acquire knowledge, skills and abilities to behave, behave, react, respond to psychological demands and instructions in relation to society, society, human life, as well as mobility, responsiveness, efficiency, diligence. to be able to achieve their goals in the field of pedagogy, to take an active part in the life of society, to be able to link the factors of development of society and to be diligent in contributing to the development of this society.

Here we can explain the concept of socio-pedagogical activity. Social (lat. Socialis - social) community, belonging to society. Pedagogical - pedagogical, peculiar. Activity (derived from the Arabic word for mobility) sensitivity; means efficiency (Explanatory Dictionary of the Uzbek language. 2006). Thus, we can express the concept of socio-pedagogical activity as follows: Sociopedagogical activity - the teacher's mobility, responsiveness, efficiency, diligence in the education of students in relation to the community, society, human life. The above definition is a description of the integration of students into the life of society, that is, active living, professional activity and socialization.

In pedagogy, socialization is inextricably linked with the process of social formation, provision, manifestation and results of the student. Therefore, the problem of preparing future teachers for socio-pedagogical activities is relevant for the following reasons:

$>$ The pedagogical role and importance of higher education institutions in the preparation of future teachers for socio-pedagogical activities is growing day by day;

$>$ The pedagogical process becomes one of the most important and significant links in the preparation of students for socio-pedagogical activities;

$>$ The issues of preparing future teachers for socio-pedagogical activities in educational institutions will become one of the current pedagogical requirements of modern times.

Today, special attention is required to the training of personnel that meet the requirements of the XXI century. The development of social activism of students will become an important factor in the period of rapid high technical development of society in all respects. At the same time, it is necessary to create pedagogical mechanisms for the development of social activity in students of pedagogy and psychology of higher education institutions. Accordingly, the importance of ensuring the development of social activity in students of pedagogy and psychology of higher education institutions is growing rapidly. The content of the concept of developing social activity in students is enriched with innovative concepts, and it is necessary to integrate this updated content into all stages of the education system and introduce it into the educational process. An important task is the coverage of the problem of pedagogical mechanisms for the development of social activity in students of pedagogy and psychology of higher education institutions and their analysis as an object 
of scientific research.

\section{DISCUSSION}

As a result of preparing students of pedagogy and psychology of higher education institutions for socio-pedagogical activities, young people will be able to correctly analyze and differentiate between different political, economic and social situations in society. This requires professional educators to take a responsible approach to the fate of young people, to have the experience to connect their fate with the prospects of society. In preparing future pedagogical psychologists for socio-pedagogical activities, it is necessary for professional teachers to have professional intuition, to acquire certain knowledge on future development.

In pedagogy, student socialization is divided into three main states: activity, behavior, and selfawareness. The integration of students into society is associated with a number of needs, political, economic, social environment and requirements (Mahfuza M. Alikulova, Zulfiya A. Dekhkambaeva. 2018). The main task of socialization is to develop students' thinking in relation to the professional needs, problems, requirements and opportunities that exist in society. On the one hand, there seems to be a lot of research on social activism, socialization. In fact, concepts such as social activism and socialization are philosophical, pedagogical-psychological and sociological categories of a national nature. In this context, this problem is often limited to consideration in the context of personality formation issues.

The problem of creating pedagogical mechanisms for preparing students of pedagogy and psychology of higher education institutions for socio-pedagogical activities is also related to improving the management of the higher education system. Management of the pedagogical process is an integral part of social management, and the need to improve it is a pressing problem of continuing education. Accordingly, this issue is in the constant focus of higher education institutions, leaders and organizers of continuing education, as well as scientists and researchers working in the field of pedagogy.

Creation of mechanisms for preparation of future pedagogical psychologists for social and pedagogical activity; depends on the accuracy of the tasks performed, the correct distribution of tasks and the skillful and operational coordination of educational work on social activism.

Higher education management is an activity that requires constant improvement. It should be noted that a higher education institution is a mechanism with an internal structure (Djuraev RH, Turgunov ST 2006). Each part of it requires only discipline, creativity, and reliance on scientific advances. It is also an important task to effectively manage the educational process and prepare future pedagogical psychologists for socio-pedagogical activities to achieve high results. Analyzing the problem of preparing students for socio-pedagogical activities in the management of higher education, it should be noted that the purpose of higher education institutions is to train highly qualified specialists. In this context, it is important that the management of the activities of professors and teachers through the directions, faculties and departments of higher education institutions is entrusted to the scientific and pedagogical councils.

Management of higher education institutions is based on the principle of individual leadership, training of future pedagogical psychologists as highly qualified specialists and creating all opportunities for them to know the content and essence of the educational process of complex social activity. The importance of the principle of individual leadership in the management of higher education institutions is that there are factors that prepare future teachers for socio-pedagogical activities.

The team of educational institutions is an important part of pedagogical activity, organizes education, 
defines the content and essence, substantiates from a scientific and methodological point of view, determines the order of performance of the main tasks of development of future pedagogical psychologists. At the same time, in the preparation of future teachers for socio-pedagogical activities, represents and analyzes a certain area of social relations in society, its development, the laws of youth education. It is connected with the improvement of higher education management and the improvement of organization in the field of education, the introduction of clarity in educational work, the improvement of the quality of education.

The need to improve the management and supervision of higher education institutions has become even more practical with the adoption of the Law "On Education" and its full implementation in the system of continuing education. This process expands the opportunities to provide students with knowledge about social activism by preparing future teachers for socio-pedagogical activities in higher education institutions. In order to organize educational work at the level of requirements aimed at the content of preparation of future pedagogical psychologists for socio-pedagogical activities, it was determined to pay attention to the following:

$>$ The inclusion of materials on the development of socio-pedagogical activities in the content of curricula, reports on disciplines, broad expression, methodological justification;

$>$ Equipping classrooms with materials related to the development of social and pedagogical activities of students;

$>$ provision with modern technical means;

$>$ Providing students with textbooks, manuals, scientific and methodological literature, a set of electronic information on the development of social and pedagogical activities;

$>$ providing students with didactic materials on social activity;

$>$ creating a favorable creative psychological, creative atmosphere in the audience, emphasizing the importance of human socialization;

$>$ Creating a creative environment for teaching and learning materials for the development of sociopedagogical activities in the teaching staff.

\section{RESULTS}

Attention to the improvement of the methodological, legal, material and technical base of higher education institutions and the continuation of this process play an important role in preparing students for socio-pedagogical activities. The main results of this are reflected in the following; 1) manifested in the constant development of the doctrine of the goals and objectives of national education; 2) the idea of creating mechanisms for the development of social activity of students in the content of reforms and improvement of education in higher education institutions and its practical status.

Improving the management of higher education institutions requires the conduct of educational work in accordance with the requirements of higher education. As a result, the implementation of monitoring in educational institutions has become an important source and tool for independent study of issues related to the preparation of future pedagogical psychologists for socio-pedagogical activities. The organization of independent work in the field of preparation of students for social and pedagogical activities in the educational institution at a high scientific and pedagogical level, improves knowledge of social activism, educational work. As a result, it is an important mechanism in preparing students for socio-pedagogical activities.

There are specific organizational features in the educational work of higher education institutions 
that train future pedagogical psychologists. One of these features is the organization of the process in a way that meets the requirements of continuing education, achieving harmony in the creative, educational work of the teaching staff as a result of the creation of a purely psychological situation in the educational institution. It should be noted that the development of scientific research in the field of pedagogical sciences has created a need to conduct in connection with the approach to social activism from the main directions of improving education. Consequently, issues related to the theory and practice of education; the content of education, the principles of education, the form, style and means of teaching, require a more perfect organization of education.

Responsible leaders of the educational institution, scientists, organizers of the educational process in the process of leading the organization of preparation of students for socio-pedagogical activities raise the issue of effective use of modern textbooks, scientific, theoretical, methodological and general pedagogical literature. As part of measures to improve the training of future teachers and psychologists in education, changes are made to the curriculum. Also, such a solution to the problem, that is, the content of the development of the preparation of future teachers for socio-pedagogical activities, plays an important role. It should be noted that the learning process is aimed at designing the near future in accordance with the requirements of education. The general and specific purpose of higher education for the training of future pedagogical psychologists is to determine the set of subjects taught, to improve them on the basis of modern requirements, the content of each subject included in the curriculum, the total amount of teaching materials taking into account the total employment of students. includes.

As a result of educational reforms, the implementation of educational work aimed at preparing young people, including students of pedagogy and psychology of higher education institutions for sociopedagogical activities, the organization of the educational process at the level of international standards, ie changes in curricula, social activism significant results were achieved, such as increasing the number. The content of topics related to social activity in the disciplines directly taught has been improved, and materials, textbooks and manuals on the preparation of future pedagogical psychologists for socio-pedagogical activity have been included. The role of sociopedagogical activity in the life of every future teacher-psychologist is reflected in the activities of scientific seminars, educational talks, scientific conferences and scientific circles. The practice of conducting scientific discussions and analysis of the results of socio-pedagogical activities has begun. Another important aspect of the issue is that students - future pedagogical psychologists, educators - were widely involved in these conferences as supporters of the youth social movement.

\section{METHODOLOGY}

The methodology of using materials related to the preparation of future teachers for sociopedagogical activities in the classroom requires regular didactic (or educational) analysis. This type of analysis involves the scientificity and consistency of the topic, the orientation from simple to complex, the scientific nature of the information provided, the new information on global, regional, local social activity, their disclosure in vivid and fluent language.

The method of methodological analysis is also used in the integration of educational materials on the preparation of future teachers for socio-pedagogical activities in the context of related disciplines of pedagogy taught in higher education. In this case, the teacher has two aspects of creative activity:

First, to be able to deliver material on the preparation of students for socio-pedagogical activities to the subject at the intended time in the program, using what methods, taking into account the age and personal-psychological characteristics of students, directing them to creative research and creating opportunities for them; 
Second, the experience of the educator is expected to demonstrate the level of scientific and methodological training. When analyzing the second aspect of the pedagogical activity, his creativity and methodological skills should be taken into account. Advanced pedagogical and innovative experience of the teacher is reflected in the explanation of materials related to the preparation of students for socio-pedagogical activities.

It is expedient to use the method of methodological analysis in the process of higher education. This analysis includes the decisions of the Cabinet of Ministers of the Republic of Uzbekistan, the Ministry of Higher and Secondary Special Education, the state language, the national spirit, the masterpieces of culture, the works of great scholars and scientists in this field. based on the use of the latest innovations in preparation for activities.

It is expedient to use the method of psychological analysis, which is carried out by specialists in higher education institutions in the teaching of lessons on topics related to the preparation of students for socio-pedagogical activities. In this method and analysis of the teaching process, first of all, attention is paid to the preparation of students for the lesson, their health, healthy environment in the community, interest in a particular subject, the methods used by the teacher during the lecture, seminar. It also includes aspects such as students' responsiveness, sensitivity, resourcefulness, recall of new and past material related to social activity, figurative, logical thinking, imagination, willingness or unwillingness, and the extent of their knowledge, skills, and abilities. The educator is aware of the emergency situation, has a high level of culture, is armed with knowledge of social activism, has the ability to manage the audience, adheres to the competence of interaction with students and can easily get out of the psychological situation, self-management in the current situation are also taken into account.

The method of pedagogical analysis is also used in the study of the teaching process of pedagogical disciplines taught in educational institutions. This type of lesson analysis is complex and responsible, it implies the general competence of the teacher, communication skills with students, the ability to provide specific knowledge of the educational content of preparation for socio-pedagogical activities in the classroom, the provision of scientific information and the speaker. It is also important to fulfill the tasks of inculcating the values of spiritual perfection, economic, moral, labor, sophistication, along with socio-pedagogical activities during the course.

Improving the system of control and monitoring in higher education institutions, in turn, is aimed at ensuring the effectiveness of activities aimed at developing the competence of the departments to prepare future pedagogical psychologists for socio-pedagogical activities. During this process, it is possible to improve the quality of lessons on social activism for students, to achieve the expected goal of these lessons, resulting in the training of highly qualified pedagogical specialists, to improve the mechanisms for preparing future pedagogical psychologists for socio-pedagogical activities.

It should be noted that in the process of raising the level of social activism of students, preparing future teachers and psychologists for socio-pedagogical activities, it is important to coordinate the educational work of the departments with the activities of the faculties or scientific analysis of certain stages in the implementation of activities. . It is also advisable to make effective use of the scientific database of social activity in the preparation of a well-founded work program of the system, a set of planned activities.

In the process of monitoring the management process in higher pedagogical educational institutions, forms and methods of leading the educational process, analyzing the activities of those responsible for educational work in the institution, attention is paid to the specifics of working with students, mastering knowledge of future teachers and psychologists. they seek ways to achieve sociopedagogical activity on a scientific basis. 
In the system of higher education, the task of achieving the goals of education is mainly assigned to the staff of the institution. This, in turn, is related to the scientific and pedagogical activities of professors and teachers working in leadership positions. It should be noted that if the internal control of institutions is organized on a scientific basis, in a manner consistent with the reforms, a high level of performance is achieved in education, including the preparation of future pedagogical psychologists for socio-pedagogical activities. Education serves to train the professionals needed by civil society. The science-based division of labor in higher education institutions is an important factor in educational work. Naturally, the existence of such a work schedule requires that the educational process be organized on a scientific basis, purposeful, taking into account the individual and the prospects of our country. The high level of organization of the teaching process in all disciplines is part of the development of the future pedagogue-psychologist, the training of highly qualified specialists and, as a result, the training of specialists who have achieved socio-pedagogical activity. Improving internal control in educational institutions plays an important role in the implementation of such science-based educational work. The common denominator in this process is that due to the monitoring of the teaching process, the department provides lectures, practical classes and creative cooperation between students. As a result of this scientific cooperation, students work independently on topics related to preparation for socio-pedagogical activities, which should be studied independently, and creative results are achieved. The scope of the monitoring work provides an opportunity to get acquainted with the activities of student scientific circles under the departments and, as a result, to intensify the participation of students in the circles.

In the process of improving the mechanisms of preparation of future teachers for socio-pedagogical activities, it is necessary to have knowledge, skills and abilities in the methodology of pedagogical sciences, innovative teaching technologies. It is necessary to understand the content, the purpose of the problems of education and upbringing in the educational institution. It should be noted that without them it is impossible to find optimal ways to prepare students for socio-pedagogical activities.

Pedagogy and psychology are included in the plan of social activities with students in extracurricular activities. In particular, the discussion of the results of these scientific and social activities with the youth in cooperation with representatives of non-governmental and non-profit organizations of Uzbekistan played an important role in developing the competence of future teachers and psychologists in preparing for social and pedagogical activities. The future pedagogue-psychologist will be able to directly imagine the purpose, content, importance of social activities, which he can demonstrate in the future. Also, students who want to become teachers-psychologists are given the opportunity to study as independent research topics, abstracts, coursework, graduate work, covering various aspects of socio-pedagogical activities, which leads to an expansion of knowledge about social activism in their thinking. Students are working on the preparation of independent work, course work on the subject, ie on topics related to socio-pedagogical activities, comparing teaching materials with issues related to socio-pedagogical activities and coming to independent conclusions. Prospective teachers are invited by the supervisor to independently study the topic of sociopedagogical activities and to speak at a scientific seminar, round table discussion on sociopedagogical activities, which will arouse their interest in this social issue and help them understand the essence of social activism. . As a result, students play an important role in the development of social and pedagogical competence.

\section{RECOMMENDATIONS}

The problem of modern pedagogical disciplines is to strengthen the educational significance of education in preparing students for socio-pedagogical activities. The educator's deep knowledge of topics related to social activity is of educational importance. But the most important and important 
for the student is the teacher's thirst for knowledge of socio-pedagogical activities, encourages students to research, independent acquisition of knowledge, understanding the essence of science, creative approach to the study of socio-pedagogical activities and free thinking, independent, creative work. conditions.

There are several methods of monitoring the lessons conducted in higher education institutions to prepare future teachers for socio-pedagogical activities. Observers are allowed to enter the classroom together with the teacher, ie through direct participation in the lesson or through electronic control methods. The methodological support of the teacher, such as group journal, working curriculum, calendar-thematic plan, allows the teacher to conduct the lesson at a high level.

In the course of our research, it became clear that the pedagogue should pay attention to the following in the organization of an integrated method of integrating resources into the content of the lesson to prepare students for socio-pedagogical activities:

$>$ Demonstration of the teacher's level of preparation for the lesson and his ability to explain the topic using materials for the preparation of future teachers for socio-pedagogical activities;

$>$ the presence of the teacher in the curriculum and various developments on the topic, didactic handouts on the preparation of future teachers for socio-pedagogical activities, the preparation of visual aids;

$>$ monitor and analyze the readiness of the teacher for the lesson, the ability to use materials to prepare students for socio-pedagogical activities, the degree to which these materials are understandable to students, the level of interest in them during the lesson;

$>$ pay special attention to explaining the content of materials related to the preparation of students for socio-pedagogical activities in setting the goals and objectives of the lesson;

$>$ The teacher should set a clear goal for each lesson by explaining the essence of the topic, reflecting the preparation of students for socio-pedagogical activities, correctly explain the purpose of the mechanisms related to the development of socio-pedagogical competence, clearly define the responsibilities of teachers and students;

$>$ It is advisable to pay special attention to the general preparation of the audience during the analysis of organizational work. In particular, the presence of students in the classroom, the focus on the topic of the lesson, the use of visual aids, technical aids and the presence of teachings on socio-pedagogical activities in the presentations;

$>$ General preparation of the classroom for lessons, creative environment aimed at social and pedagogical activities of students, cleanliness of classrooms and desks, cleanliness of the auditorium, the presence of chalk and damp cloth, readiness of computer equipment, the appearance of teachers and students.

\section{CONCLUSION}

The general educational impact and effectiveness of the lesson play an important role in improving the pedagogical mechanisms of preparation of future teachers for socio-pedagogical activities. It should be noted that such an approach to the teaching process is the scientific basis of pedagogical analysis. It is also important to emphasize the role of experienced professors in raising the spiritual thinking of students and the impact of informative, science-based lectures, which promote the preparation of meaningful, future teachers for socio-pedagogical activities.

The role of pedagogical cooperation in the study of materials related to socio-pedagogical activity of future pedagogical psychologists is analyzed, and it is expedient to pay attention to the following. 
First, to teach students to think on the basis of information aimed at preparing them for sociopedagogical activities;

Second, to provide students with independent conclusions and materials on preparation for sociopedagogical activities, independent study, reflection and expression of opinion;

Third, to teach students to have independent research in the preparation of materials for sociopedagogical activities, to find answers to questions posed by the effective use of modern media;

Fourth, as a result of studying the materials of the lesson, the student will be able to think independently - to provide themselves with the concept of socio-pedagogical activity.

It is expedient to use the final analysis in the study of the general level of lessons organized by students of pedagogy and psychology in higher education institutions, the level of use of materials related to the preparation for socio-pedagogical activities in the lessons. In this process, various suggestions, guidelines, conclusions on the professional training of the teacher, pedagogical experience, methodological skills, being a highly qualified specialist are described. In the process of analyzing the pedagogical mechanisms of preparation of students for socio-pedagogical activities and integrated lessons, new proposals on socio-pedagogical activities can be introduced, recommendations for improving the level of lessons can be made. During the final analysis of the lesson, the experts took into account the use of materials aimed at preparing future pedagogical psychologists for socio-pedagogical activities, the educational value of the lesson and the achievement of the intended purpose. Such an approach to the analysis of the research expands the possibility of improving the pedagogical mechanisms of the system of preparation of future teachers for socio-pedagogical activities in the classroom.

\section{REFERENCES}

1. Mirziyoev Sh.M. We will resolutely continue our path of national development and raise it to a new level. - Tashkent: "Uzbekistan". 2017 y.

2. Annotated dictionary of the Uzbek language. The fourth volume. State Scientific Publishing House "National Encyclopedia of Uzbekistan", Tashkent, 2006. 606 pages.

3. Djuraev R.X., Turgunov S.T. Educational pedagogue-psychologist. Tashkent, «Voris-publishing house», 2006. 264.

4. Mahfuza M. Alikulova, Zulfiya A. Dekhkambaeva. Improving Educational Work among Minors as Important Factor of Preventing Spiritual Threats. Eastern European Scientific Journal. DOI 10.12851 / EESJ201808. 220-232. 